\title{
Outdoor Performance Evaluation of Building Integrated Photovoltaic Thermal (BIPVT) Solar Collector with Spiral Flow Absorber Configurations
}

\author{
Adnan Ibrahim, Sohif Mat, Ahmad Fudholi, Ahmad Fazlizan Abdullah and Kamaruzzaman Sopian \\ Solar Energy Research Institute, Universiti Kebangsaan Malaysia, Selangor, Malaysia
}

\begin{tabular}{l} 
Article Info \\
\hline Article history: \\
Received Jun 12, 2018 \\
Revised Aug 29, 2018 \\
Accepted Sep 30, 2018 \\
\hline Keyword: \\
Absorber \\
BIPVT \\
Electrical efficiency \\
Spiral flow \\
Thermal efficiency
\end{tabular}

\section{Corresponding Author:}

Adnan Ibrahim,

Solar Energy Research Institute,

Universiti Kebangsaan Malaysia (UKM), 43600, Bangi, Selangor, Malaysia.

Email: iadnan@ukm.edu.my

\begin{abstract}
Building Integrated Photovoltaic thermal solar collector (BIPVT) with Spiral flow absorber design is a collector not only used to generate electricity and thermal energy simultaneously but also can be integrated with the roof. Due to it characteristic as a roof, the collector is exposed to the direct sunlight resulting from a higher temperature on it surfaces. The temperature increased will simultaneously decrease it efficiency. An experiment has been conducted outdoor at Universiti Kebangsaan Malaysia to examine and evaluate the efficiency of the collector. Data for the experiment has been collected and gathered from 08:00 to 17:00 respectively. Results from the experiment recorded the best total efficiency of $65.10 \%$ (53.64\% thermal efficiency and $11.46 \%$ electrical efficiency from the PV panel) at mass flow rate of $0.041 \mathrm{~kg} / \mathrm{s}$ and solar radiation of $1148 \mathrm{~W} / \mathrm{m}^{2}$. The effect of mass flow rates on open circuit voltage $\left(\mathrm{V}_{\mathrm{oc}}\right)$ and the modules short circuit current $\left(\mathrm{I}_{\mathrm{sc}}\right)$ are also presented.
\end{abstract}

Copyright $\odot 2018$ Institute of Advanced Engineering and Science. All rights reserved.

\section{INTRODUCTION}

Photovoltaic (PV) system is an attractive application that integrated into the building [1]. However, due to the direct exposure from the sunlight and leads to temperature rises to $70^{\circ} \mathrm{C}$ resulting decreases in it efficiency [2]. Hence, it is crucial to reduce the temperature, simultaneously, optimize the efficiency throughout the system. The solar energy generated by the system not only converted into electricity; some will convert into thermal (heat), thus, by combining the system capable to produced higher output energy [3]. Heat that produced by the module will be collected by the absorber collector and drained through the tank for other purposes. The transferring of heat away from the module manages to reduce the temperature rises in the system and simultaneously capable to maintain the performance and efficiency [4]. The problems such as low efficiency, uniformity architectural and limited roof space for separate system installation had become important factors that influenced the idea of combining the photovoltaic/thermal (PVT) system into one complete system [5]. PVT solar collectors convert solar radiation directly to both thermal and electrical energies. PVT solar collector applications are becoming more widely accepted in meeting industrial and residential electric and thermal energy demand after decades of development and variety of incentive programs. Hot water is essential for industrial and domestic applications. It is required for bathe, wash clothes and kitchen utensils and other domestic utilities are the same in the city or out of town. Thermal energy (hot water) is also needed in quantities in hotels, hospitals, dorms and industries such as textiles, paper and food processing [6].

This paper discusses on the aspect of novelty of building integrated photovoltaic thermal solar collector (BIPVT) designed to produce both electricity and hot-water system. Besides generating "free" 
electricity, the BIPVT also produced hot water at the useful temperature for the applications such as residential as well as many industrial, including agricultural and commercial buildings that require low-grade heat. The motivation behind the development of the BIPVT collector is twofold; it, firstly, is to produce a collector that expends the use of existing roofing and cladding product by adding the value-added invention to it, secondly, to produce a highly efficient PV power and solar hot-water system that suitable domestic usage [7].

\section{THE PROBLEM}

The main problems with the conventional photovoltaic and thermal collectors are depending on the design of the absorber collector. Today, most of the available designs for flat plate collectors are with conventional parallel design. This type of design produces non-uniform cooling due to its low efficiency at a high-temperature problem. Proper design of the absorber collector with special configuration enables the fluid to flow and sustain the energy inside the absorber collector need to be design and examine. It is well known that the flat plate collector is considered as an expensive product in the market [8]. The high cost is not only due to the material of the collector but also due to the material for the absorber collector and complete system, including the installation. An appropriate design of the absorber collector is a necessity to not only cool the cells and increase it efficiency, but in appropriate applications, the thermal energy is equally valuable. Besides that, due to the problem of low efficiency, payback period for the particular system is high [9]. The efficiency of a separate systems (photovoltaic cells and solar thermal) are calculated as separate entity. Since that, the system consists of two separate systems, the calculation of efficiency needs to be dividing into two. Where else, after combining the system (photovoltaic thermal system), the thermal collector and photovoltaic are treated as single entity and the area is divided only to one. By integrate the system, theoretically, not only increase the efficiency tremendously but also directly integrated into the roofing material for a building, minimized the usage of space of installation for both systems.

\section{PROPOSED SOLUTION}

The new prototype design of BIPVT absorber collector, namely spiral flow absorber collector, has been designed and fabricated as in Figure 1 [10]. The absorbers in the form of rectangular hollow tubes are attached closely underneath the PV module with metallic bonded, and this will ensure a zero gap or no gap between the tubes and the module, in which heat can be transferred [11]. The zero gap is essential to ensure the high efficiency and excellent bonding quality between the collector and the sheet underneath the cell (module) [12]. The absorber collector, as shown in Figure 1, is made of a rectangular hollow tube of stainless steel material with the dimension of $\left(D_{h}\right) 12.7 \times 12.7 \mathrm{~mm}$

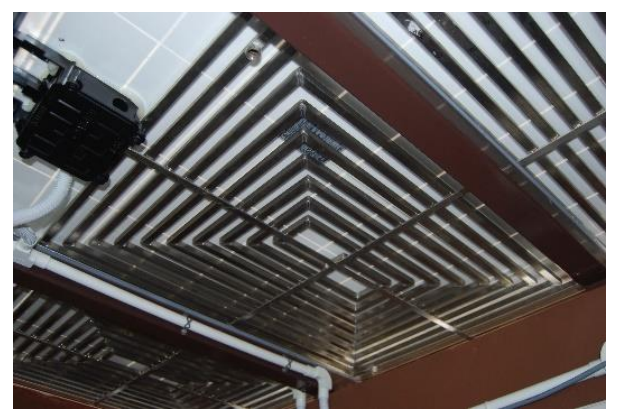

Figure 1. The spiral flow absorber collector design

A standard commercial photovoltaic module of a flat plate single glazing sheet of polycrystalline silicon with single glazing sheet has been laminated and bonded with a high-temperature silicone adhesive and sealant. Once sealed and watertight, the absorber collector is attached to the bottom side of photovoltaic module and encapsulated in a Polyvinyl resin and formed a complete BIPVT system. Later, thermal insulator is packed underneath the absorber collector to prevent heat from escaping further and provides more uniform temperatures throughout the collector. The absorber collector is designed in the form of continuous coil or tube configuration and consists of at least one inlet and one outlet to allow the medium (water) to enter and to exit from the coil respectively and covered the entire photovoltaic module surfaces. 
In this outdoor experiment, the hot-water storage is located as near as possible to the collector to maintain the water flow from the pump to the collector and vice versa. The water storage is connecting to the flat plate collector through sets of pipes and connected with a pump that controls the water circulating. It is assuming that the pipes are well insulating to prevent from any heat lost to occur and only the collector unit absorbs the energy. The inlet water temperature at the collector is assuming the same as the mean water temperature inside the storage tank. To accommodate the outdoor experiment, a fabricated BIPVT collector is mounting onto a shed. The shed is constructed with a mild steel frame and cover with plywood materials. The BIPVT collector is later, installed on top of the shed as the rooftop. The PV module manufacturer recommended the tiled angle of $14^{\circ}$ to be the best-tilted angle for sites located at $0^{\circ}-14^{\circ}$ latitude. A silicone gel is used as a joining agent between solar modules and the mounting surface. The pyranometer is fixed on top of the module's frame with the same tilted angle as the PV module. The outdoor experiment has been performed at the Solar Energy Research Institute (SERI) Solar Park, Universiti Kebangsaan Malaysia. In this experiment, ambient temperature and other temperatures are measured using T-type thermocouples. Solar radiations from the sun are measured using Eppley pyranometer. In this experiment, eight modules of photovoltaic solar panels are attached and connected in parallel. Mass flow rates ranging from 0.027, 0.035 and $0.041 \mathrm{~kg} / \mathrm{s}$ and data-acquisition system for the collector are later connected to the computer.

\section{COMPARISON WITH PREVIOUS STUDY}

According to Kim et al., $[13,14]$ the achievement of the thermal and photovoltaic collectors are not only related to the cover or without the cover but based on the formation of the term collector may also give an impression on the achievements of PVT solar collectors. They use a rectangular channel to expand the surface area of heat displacement. Zondag et al. [15] have made a comparison of electrical resistance between conventional photovoltaic collectors, PVT collectors and PVT collectors with and without glass cover. The annual average of electrically generated emissions is $7.2 \%, 7.6 \%$ and $6.6 \%$. PVT collectors without cover provide the highest electrical efficiency. Experiment study by Ji et al. [16] on natural circulation hybrid PVT water heating system has been conducted. They reported that the PVT efficiency about 55\% with $45 \%$ thermal efficiency and PV efficiency of $10.1 \%$. conclude that the thermal efficiency reached about $40 \%$ when the initial temperature in the system is same as the daily mean ambient temperature. The PVT efficiency about $50 \%$ with $40 \%$ thermal efficiency and the PV efficiency of 9.87 .

\section{PERFORMANCE EVALUATION OF BIPVT SOLAR COLLECTOR}

The efficiency of the photovoltaic cells is depending on the temperature [17]. Further, the performance of BIPVT collectors can be depicted by the combination of efficiency expression [18]. It comprised of the thermal efficiency $\eta_{t h}$ and the PV panel efficiency $\eta_{P V}$, which usually include the ratio of the useful thermal gain and electrical (PV panel) gain from the system to the incident solar irradiation on the collector's gap within a specific time or period. As shown in Equation 1, the total efficiency $\eta_{t o t}$ is used to evaluate the overall performance of the system.

$$
\eta_{t o t}=\eta_{t h}+\eta_{P V}
$$

The thermal efficiency $\left(\eta_{t h}\right)$ of the conventional BIPVT collector is calculate using the Equation 2.

$$
\eta_{t h}=\frac{Q_{u}}{G}
$$

Where $Q_{u}$ is the actual useful collected heat gain $\left(\mathrm{W} / \mathrm{m}^{2}\right)$ and $\mathrm{G}$ is the measurement of incoming solar irradiation on the collector surface $\left(\mathrm{W} / \mathrm{m}^{2}\right)$. Using Equation 2, the useful collected heat $\left(\mathrm{Q}_{\mathrm{u}}\right)$ collected by the water in terms of its temperature rise can be explored further using the Equation 3 derived from HottelWhillier equations [17]:

$$
Q_{u}=A_{c} F_{R}\left[G_{T}(\tau \alpha)_{P V}-U_{L}\left(T_{i}-T_{a}\right)\right]
$$


Where $T_{i}$ is inlet temperature, $T_{a}$ is ambient temperature, $\mathrm{U}_{\mathrm{L}}$ is overall collector heat loss, $\mathrm{G}_{\mathrm{T}}$ is solar radiation at NOCT (radiation level $800 \mathrm{~W} / \mathrm{m}^{2}$, ambient temperature $26^{\circ} \mathrm{C}$ and wind velocity $1 \mathrm{~m} / \mathrm{s}$ ), $(\tau \alpha)_{P V}$ is PV thermal efficiency, Further, the collector area $A_{c}$ and is the collector area and heat removal efficiency factor $\mathrm{F}_{\mathrm{R}}$ and $F^{\prime}$ is collector efficiency factor can be calculated based on Equation 4:

$$
F_{R}=\frac{\dot{m} C_{p}}{A_{c} U_{L}}\left[1-\exp \left(-\frac{A_{c} U_{L} F^{\prime}}{\dot{m} C_{p}}\right)\right]
$$

Based from the Equation 1 to 4 , it is then possible to calculate the useful heat gain produced by the PVT collector. By rearranging the formulae, the thermal efficiency of the collector can be written as in Equation 5 [19]:

$$
\eta_{t h}=F_{R}(\tau \alpha)_{P V}-F_{R} U_{L}\left(\frac{T_{i}-T_{a}}{G_{T}}\right)
$$

Furthermore, to evaluate the fluid mass flow rates which later can be used to analyze the thermal performance $\eta_{t h}$ of the BIPVT, the Equation 6 can be use based on Hottel and Whillier equations

$$
\dot{m}=\rho A v_{a v}
$$

Where $\rho$ is the density of the fluid in drain input area and $v_{a v}$ is the fluid velocity. For Power, $P$ is the result of current, $I(V)$ in current-voltage dependent, therefore, the thermal efficiency of the collector can be expressed further in Equation 7:

$$
\eta_{t h}=\frac{\dot{m} C_{p} \Delta T}{A_{p} G_{T}}
$$

Where $\dot{m}$ the mass flow rate, $\Delta$ is the differences between fluid outlet temperature and fluid inlet temperature $(K), A_{p}$ is the area covered by absorber collector and $\mathrm{G}_{\mathrm{T}}$ is referred to the solar radiation at NOCT. For panel efficiency of the collector, Equation 8 , can be used to identify efficiency for temperaturedependent PV panel efficiency of the BIPVT module [20]:

$$
\eta_{p v}=\eta_{r}\left(1-\gamma\left(T_{c}-T_{r}\right)\right)
$$

Where $\eta_{p v}$ is the PV panel efficiency, $\eta_{r}$ is the reference efficiency of PV panel $\left(\eta_{\mathrm{r}}=0.12\right), \gamma$ is the temperature coefficient $\left({ }^{\circ} \mathrm{C} 0.0045^{\circ} \mathrm{C}^{-1}\right), T_{r}$ is the reference temperature and $T_{c}$ is the temperature of the solar cell (K).

\section{RESULTS AND OBSERVATIONS}

Average data for the outdoor experiment for the collector has been collected and gathered from 08:00 to 17:00 respectively. It is recommended that the most suitable time for weather data to be collected is from 11:00 to 15:00 [21, 22]. During the experiment, data were recorded for every 10 seconds and later summed up to the average of 1 minute.

\subsection{The effect of Mass Flow Rates on Open Circuit Voltage $\left(V_{o c}\right)$ and the Modules Short Circuit Current ( $\left.\mathbf{I}_{\mathrm{sc}}\right)$}

For the changes of $\mathrm{V}_{\mathrm{oc}}$ and $\mathrm{I}_{\mathrm{sc}}$ for the collector at mass flow rate of $0.027 \mathrm{~kg} / \mathrm{s}$ these changes can be clearly seen as in Figure 2 shows that the $\mathrm{V}_{\mathrm{oc}}$ increased from $0.06 \mathrm{~V}$ to $4.1 \mathrm{~V}$ while the $\mathrm{I}_{\mathrm{sc}}$ increased from 27.6A to 55.6A. For the changes of $\mathrm{V}_{\mathrm{oc}}$ and $\mathrm{I}_{\mathrm{sc}}$ for the collector at mass flow rate of $0.035 \mathrm{~kg} / \mathrm{s}$ these changes can be clearly seen as in Figure 3 shows that the $\mathrm{V}_{\text {oc }}$ increased from $2.6 \mathrm{~V}$ to $4.1 \mathrm{~V}$ before it dropped due to the bad weather, while the $\mathrm{I}_{\mathrm{sc}}$ increased from 70.1.6A to 81.5A and dropped. As in Figure 4, at mass flow rate of $0.041 \mathrm{~kg} / \mathrm{s}$, the changes of $\mathrm{V}_{\text {oc }}$ shown an increased from $3.3 \mathrm{~V}$ to $3.5 \mathrm{~V}$ while the $\mathrm{I}_{\mathrm{sc}}$ decreased from $68.4 \mathrm{~A}$ to $62 \mathrm{~A}$ due to bad weather. The $\mathrm{I}_{\mathrm{sc}}$ and $\mathrm{V}_{\mathrm{oc}}$ experiencing fluctuation when solar irradiance $\mathrm{S}$ and PV module temperature $\mathrm{T}_{\mathrm{s}}$ were changed. It can be observed that the $\mathrm{I}_{\mathrm{sc}}$ was more sensitive towards any changes of solar

Outdoor Perfomance Evaluation of Building Integrated Photovoltaic Thermal (BIPVT)... (Adnan Ibrahim) 
irradiance $\mathrm{S}$ and experiencing small changes in current to every change of PV module temperature $\mathrm{T}_{\mathrm{S}}$. Oppositely, the $\mathrm{V}_{\mathrm{oc}}$ was more sensitive to any changes of PV module temperature $\mathrm{T}_{\mathrm{s}}$ comparing to solar irradiance S. Due to that factor; it can be concluded that the change of $\mathrm{I}_{\mathrm{sc}}$ is directly influenced by the solar irradiance $\mathrm{S}$ and changes of $\mathrm{V}_{\mathrm{oc}}$ is directly influenced by the PV module temperature $\mathrm{T}_{\mathrm{s}}$. The result shows that the $\mathrm{I}_{\mathrm{sc}}$ increased when the solar irradiance $\mathrm{S}$ increased and $\mathrm{V}_{\mathrm{oc}}$ dropped when the temperature increased.

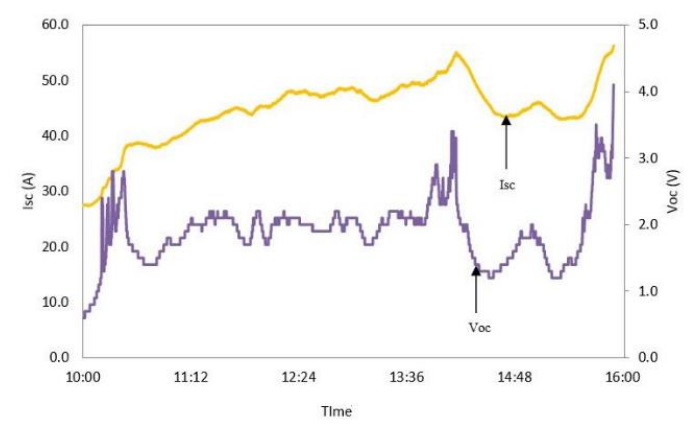

Figure 2. The Changes of $\mathrm{V}_{\mathrm{oc}}$ and $\mathrm{I}_{\mathrm{sc}}$ for the Collector at Mass Flow Rate of $0.027 \mathrm{~kg} / \mathrm{s}$

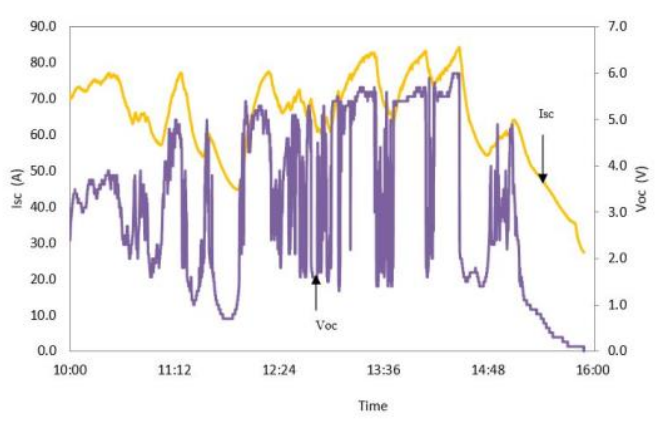

Figure 3. The Changes of $\mathrm{V}_{\mathrm{oc}}$ and $\mathrm{I}_{\mathrm{sc}}$ for the Collector at Mass Flow Rate of $0.035 \mathrm{~kg} / \mathrm{s}$

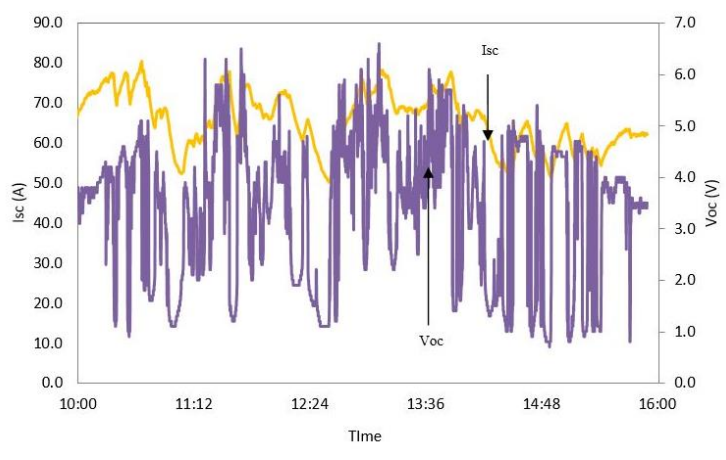

Figure 4. The Changes of $\mathrm{V}_{\mathrm{oc}}$ and $\mathrm{I}_{\mathrm{sc}}$ for the Collector at Mass Flow Rate of $0.041 \mathrm{~kg} / \mathrm{s}$

\subsection{The effect of Mass Flow Rates on Efficiency $\eta$ and the Solar Irradiation, $S$}

The results gained from the experiment were gathered and analyzed to determine the efficiency of the collector. This includes the thermal efficiency, photovoltaic efficiency and the total efficiency of the collector. Figure 5 shows the changes of collector's efficiency over the time in a day based on solar irradiance $\mathrm{S}$ and mass flow rate $\dot{\mathrm{m}}$. The changes on efficiency $\eta$ for the collector can be observed from 10:00 to $16: 00$. During this time, the mass flow rate was set to $0.027 \mathrm{~kg} / \mathrm{s}$. From the observation, it was noticed that the fluctuation of the solar irradiance level influenced the efficiency of the collector. For example, during 10:00 to $14: 00$, the total efficiency was increased from $61.21 \%$ to $62.76 \%$ at solar irradiance from $152 \mathrm{~W} / \mathrm{m}^{2}$ to $924 \mathrm{~W} / \mathrm{m}^{2}$. This indicated the clear sky recorded on that day. After this period, it was noticed that the collector efficiency starting to reduce from $61.06 \%$ to $59.9 \%$. It is noticed also the change of efficiency was due to the cloudy weather on that day.

As shown in Figure 6, the total efficiency recorded at $64.24 \%$ with $53.24 \%$ thermal efficiency and $11.01 \%$ electrical efficiency. At that instant, the solar irradiance increased from $548 \mathrm{~W} / \mathrm{m}^{2}$ to $1493 \mathrm{~W} / \mathrm{m}^{2}$. The average of $62.0 \%$ total efficiency was recorded. It was also clearly observed that the solar irradiance drops to $457 \mathrm{~W} / \mathrm{m}^{2}$ with total efficiency also dropped to $33.39 \%$ at $15: 00$ onward due to bad weather condition. No significant changes in total efficiency recorded for the mass flow rate of $0.027 \mathrm{~kg} / \mathrm{s}$ and $0.035 \mathrm{~kg} / \mathrm{s}$.

As shown in Figure 7, the total efficiency recorded at $65.10 \%$ with $53.64 \%$ thermal efficiency and $11.46 \%$ electrical efficiency. At that instant, the solar irradiance increased to $1148 \mathrm{~W} / \mathrm{m}^{2}$. The average of $62.50 \%$ total efficiency was recorded. From the figure, it was also clearly observed that the solar irradiance drops to $243 \mathrm{~W} / \mathrm{m}^{2}$ with total efficiency also dropped to $31.77 \%$ at $15: 00$ onward due to bad weather 
condition (heavy rain). No significant changes in total efficiency recorded for the mass flow rate of 0.035 $\mathrm{kg} / \mathrm{s}$ and $0.041 \mathrm{~kg} / \mathrm{s}$.

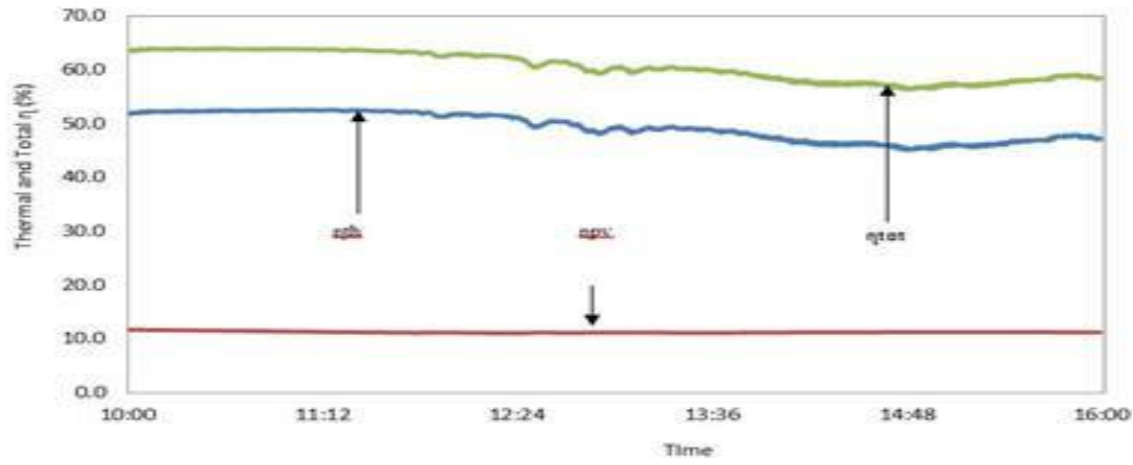

Figure 5. Changes on efficiency $\eta$ over the solar irradiance, $\mathrm{s}$ at mass flow rate of $0.027 \mathrm{~kg} / \mathrm{s}$

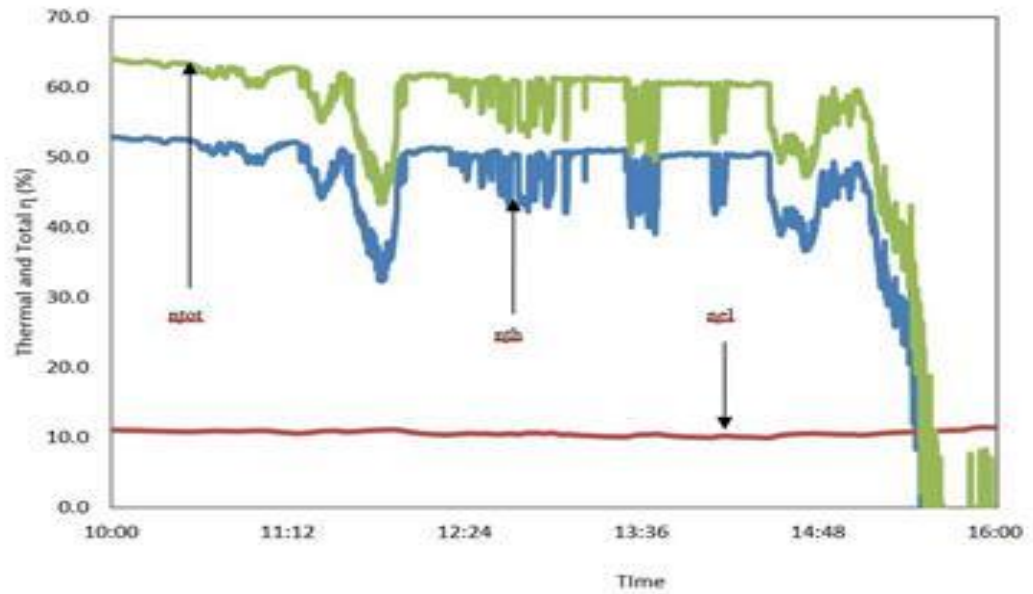

Figure 6. Changes on efficiency $\eta$ over the solar irradiance, $\mathrm{s}$ at mass flow rate of $0.035 \mathrm{~kg} / \mathrm{s}$

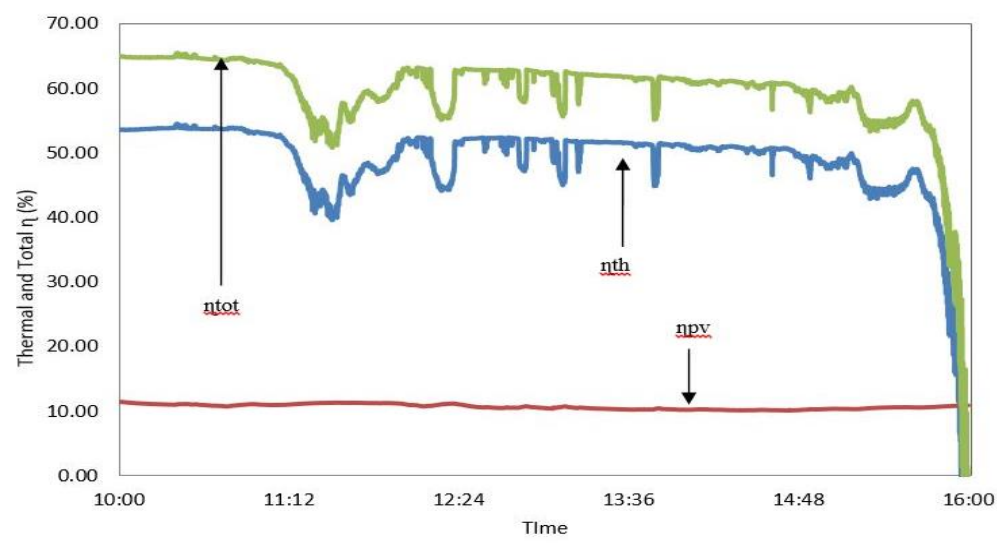

Figure 7. Changes on Efficiency $\eta$ Over the Solar Irradiance, $\mathrm{S}$ at Mass Flow Rate of $0.041 \mathrm{~kg} / \mathrm{s}$

\section{CONCLUSION}


In this experiment, the commercial polycrystalline PV module panel is used. From the results, it is observed that the major contributors to the successful of the absorber collector's design are from the design configuration. It can be notice that, the number of fins/channels play an important role to achieve higher efficiency. The more numbers of fins/channels installed to the absorber collector enable more surfaces to be covered [23, 24]. The performance of absorber collector with fins/channels can be further improved by fixing more fins/channels to the collector. Bonding quality of fins/channels needs to increase for better contact. Fin/channel and bonding quality between the collector and the sheet underneath the module often bring limitations to the overall efficiency achievable. Metallic bond needs to be applied to the fins/channels to ensure zero gap condition between the metal tubes and the PV module.

The mass flow rate plays an important factor for cooling effect on PV module temperature, including the temperature of the back wall. Increment in water mass flow rate will result to the increased of water volume entering the tubing to take away the heat, which, simultaneously reduces the PV and back wall temperature. It also notices that from the experiment, the solar irradiation increases simultaneously with the increases of $\mathrm{I}_{\mathrm{sc}}$, and $\mathrm{V}_{\mathrm{oc}}$. The outlet water temperature also reduced because of the increase in water velocity in the tubes. The solar collector performance study shows that the thermal efficiencies can reach approximately $80 \%$ based on specific collector length and mass flow rate [25].

\section{ACKNOWLEDGEMENTS}

The authors would like to thank to Universiti Kebangsaan Malaysia for funding this research (GGP2017-034) and the Solar Energy Research Institute (SERI), Universiti Kebangsaan Malaysia for providing the laboratory facilities and technical support.

\section{REFERENCES}

[1] Othman, M.Y., et al., Photovoltaic-thermal (PV/T) technology-the future energy technology. Renewable energy, 2013. 49: p. 171-174.

[2] Ibrahim, A., et al., Recent advances in flat plate photovoltaic/thermal (PV/T) solar collectors. Renewable and Sustainable Energy Reviews, 2011. 15(1): p. 352-365.

[3] Fudholi, A., et al. Energy and Exergy Analyses on Water based Photovoltaic Thermal (PVT) Collector with Spiral Flow Absorber. in 2nd International Conference on Energy Systems, Environment, Antalya, Turkey. 2013.

[4] Ibrahim, A., et al. A pilot study of the building integrated photovoltaic thermal (BIPVT) collector for commercial applications in Malaysia. in 4th WSEAS International Conference on Engineering Mechanics, Structures, Engineering Geology, EMESEG'11, 2nd International Conference on Geography and Geology 2011, WORLD$G E O^{\prime} 11$, 5th International Conference on EDEB'11. 2011. Citeseer.

[5] Zohri, M.N., Nurato; Fudholi, Ahmad, Photovoltaic Thermal (PVT) System with and Without Fins Collector: Theoretical Approach. International Journal of Power Electronics and Drive Systems, 2017. 8(4): p. 1756-1763.

[6] Fudholi, A. and K. Sopian, R\&D of Photovoltaic Thermal (PVT) Systems: an Overview. International Journal of Power Electronics and Drive System (IJPEDS), 2018. 9(2): p. 803 810.

[7] Nurul Syakirah Nazri, A.F., Mohd Hafidz Ruslan, Kamaruzzaman Sopian, Mathematical modeling of photovoltaic thermal-thermoelectric (PVT-TE) air collector. International Journal of Power Electronics and Drive Systems, 2018. 9(2): p. 795-802.

[8] Dieret. Why reneables? 2008 [cited 2008; Available from: http://www.inforse.org/europe/dieret/dieret.html. [23 May 2008].

[9] SunShot. Photovoltaics: Technologies, cost and performance. 2012 [cited 2012; Available from: http://www1.eere.energy.gov/solar/pdfs/47927_chapter4.pdf.[03 [February 2011].

[10] Ibrahim, A., et al., Efficiencies and improvement potential of building integrated photovoltaic thermal (BIPVT) system. Energy Conversion and Management, 2014. 77: p. 527-534.

[11] Rockendorf, G., et al., PV-hybrid and thermoelectric collectors. Solar Energy, 1999. 67(4-6): p. 227-237.

[12] Chow, T.T., Performance analysis of photovoltaic-thermal collector by explicit dynamic model. Solar Energy, 2003. 75(2): p. 143-152.

[13] Kim, J.-H. and J.-T. Kim, The Experimental Performance of an Unglazed PVT Collector with Two Different Absorber Types. International Journal of Photoenergy, 2012. 2012: p. 6.

[14] Kim, J.-H. and J.-T. Kim, The Experimental Performance of an Unglazed PV-thermal Collector with a Fully Wetted Absorber. Energy Procedia, 2012. 30: p. 144-151.

[15] Zondag, H.A.d.V., D. W. Van Helden, W. G. J. Van Zolingen, R. J. C. Van Steenhoven, A. A., The yield of different combined PV-thermal collector designs. Solar Energy, 2003. 74(3): p. 253-269.

[16] Ji, J., et al., A sensitivity study of a hybrid photovoltaic/thermal water-heating system with natural circulation. Applied Energy, 2007. 84(2): p. 222-237.

[17] Duffie, J.A. and W.A. Beckman, Solar engineering of thermal processes. Second ed. Vol. 216. 1991, New York: John Willey and Sons Inc. 777. 
[18] He, W., et al., Hybrid photovoltaic and thermal solar-collector designed for natural circulation of water. Applied Energy, 2006. 83(3): p. 199-210.

[19] Vokas, G., N. Christandonis, and F. Skittides, Hybrid photovoltaic-thermal systems for domestic heating and cooling--A theoretical approach. Solar Energy, 2006. 80(5): p. 607-615.

[20] Tiwari, A. and M.S. Sodha, Performance evaluation of hybrid PV/thermal water/air heating system: A parametric study. Renewable Energy, 2006. 31(15): p. 2460-2474.

[21] Garg, H.P. and R.S. Adhikari, Conventional hybrid photovoltaic/thermal (PV/T) air heating collectors: steady-state simulation. Renewable Energy, 1997. 11(3): p. 363-385.

[22] Tripanagnostopoulos, Y., Aspects and improvements of hybrid photovoltaic/thermal solar energy systems. Solar Energy, 2007. 81(9): p. 1117-1131.

[23] Chow, T.T., W. He, and J. Ji, Hybrid photovoltaic-thermosyphon water heating system for residential application. Solar Energy, 2006. 80(3): p. 298-306.

[24] Chow, T.T., et al., Performance evaluation of a PV ventilated window applying to office building of Hong Kong. Energy and Buildings, 2007. 39(6): p. 643-650.

[25] Assoa, Y.B., et al., Study of a new concept of photovoltaic-thermal hybrid collector. Solar Energy, 2007. 81(9): p. $1132-1143$. 